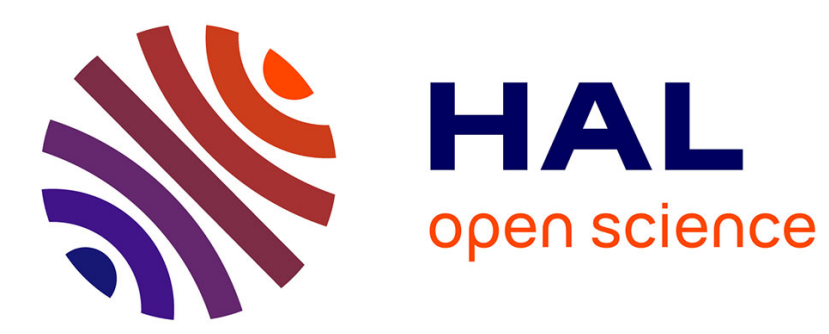

\title{
Modeling dust emissions and transport within Europe: the Ukraine march 2007 event
}

Bertrand Bessagnet, Laurent Menut, Gilles Aymoz, Hélène Chepfer, Robert Vautard

\section{- To cite this version:}

Bertrand Bessagnet, Laurent Menut, Gilles Aymoz, Hélène Chepfer, Robert Vautard. Modeling dust emissions and transport within Europe: the Ukraine march 2007 event. Journal of Geophysical Research: Atmospheres, 2008, 113 (D15), pp.art D15202. 10.1029/2007JD009541 . ineris-00963125

\section{HAL Id: ineris-00963125}

https://hal-ineris.archives-ouvertes.fr/ineris-00963125

Submitted on 17 Sep 2020

HAL is a multi-disciplinary open access archive for the deposit and dissemination of scientific research documents, whether they are published or not. The documents may come from teaching and research institutions in France or abroad, or from public or private research centers.
L'archive ouverte pluridisciplinaire HAL, est destinée au dépôt et à la diffusion de documents scientifiques de niveau recherche, publiés ou non, émanant des établissements d'enseignement et de recherche français ou étrangers, des laboratoires publics ou privés. 


\title{
Modeling dust emissions and transport within Europe: the Ukraine March 2007 event
}

\section{Bertrand BESSAGNET}

INERIS, Institut National de l'Environnement Industriel et des Risques, Parc technologique ALATA, 60550 Verneuil en Halatte, France.

\section{Laurent MENUT}

Institut P.-S. Laplace, Laboratoire de Météorologie Dynamique,

Ecole Polytechnique, 91128 Palaiseau, France.

\section{Gilles AYMOZ}

INERIS, Institut National de l'Environnement Industriel et des Risques, Parc technologique ALATA, 60550 Verneuil en Halatte, France.

\section{Hélène CHEPFER}

Institut P.-S. Laplace, Laboratoire de Météorologie Dynamique, Ecole Polytechnique, 91128 Palaiseau, France.

\section{Robert VAUTARD}

Institut P.-S. Laplace, Laboratoire des Sciences du Climat et de l'Environnement, CEA, Orme des Merisiers, 91190 Gif sur Yvette, France

\begin{abstract}
.
A dust event was observed in Europe on March 23-25, 2007. Surface observations in Central Europe showed huge concentrations of particulate matter. At the same time, dust models diagnosed a Saharan dust outbreak flowing from Sahara to Europe. However, Lidar measurements and surface stations in Eastern Europe diagnosed a dust event originating from Ukraine related to chernozemic erodible lands. Using surface and satellite measurements with modeling results, it is demonstrated that the finally huge surface concentrations recorded in the Netherlands, Belgium and the North of France were mostly due to the extremely rare Ukraine dust event whereas Saharan dust events usually produce only mid-troposphere plumes. To investigate this episode, the chemistry-transport model CHIMERE is modified in order to account for erodibility of chernozemic soil inside Europe. A size distribution for chernozemic dust emission is proposed. Over Western Europe the model reproduces the observed PM concentration peaks up to $200 \mu \mathrm{g} . \mathrm{m}^{-3}$ with a large contribution of Ukraine dust, up to $170 \mu \mathrm{g} . \mathrm{m}^{-3}$. This first model study of dust emissions due to European arable land shows that it is possible to fairly retrieve the magnitude of surface concentrations far away from the emission sources.
\end{abstract}

\section{Introduction}

Mineral dust is a natural compound in the atmosphere known to affect air quality in several regions of the world. Mineral dust emissions, transport, deposition and their impact on radiative budget have been particularly studied [Andreae and Crutzen,
1997; Sokolik et al., 2001] over the two main emittors in the world, the Western Africa and China, using worldwide measurements network, such as AERONET [Holben et al., 2001] and models such as the global model GOCART [Ginoux et al., 2004] and regional models such as, CHIMERE-DUST [Menut et al., 2007] and DREAM [Nickovic et al., 2001; 
Perez et al., 2006] over Europe and, [Park et al., 2007] among others over North-America. However, open scientific questions remain. The direct transport of mineral dust originated from arid and desert areas towards large industrialized and urbanized areas is rarely studied: one of the most important impact is the Taklamakan desert directly impacting megacities ([Sun et al., 2001; Zhang et al., 2003]), but some others studies were also done for dust transport from Africa towards Europe ([Ansmann et al., 2007; Perez et al., 2006]). Over Europe, the main impact of dust transport so far considered is that due to Western Africa dust outbreaks originated from Sahara. But the net contribution remains relatively low and, for the daily particulate matter (PM) budget, it is rare to record a dust contribution of more than $20 \%$ of the total particulate matter mass, as an averaged value over the year even if sporadic episodes led to a massive contribution of dust during short periods [Simpson et al., 1999; Querol et al., 2004a, b; Moreno et al., 2005; Escudero et al., 2007a].

This natural contribution of mineral dust to European air quality has been particularly studied in the most concerned countries: Spain [Artinano et al., 2003; Alastuey et al., 2005; Escudero et al., 2007b; Querol et al., 2007], Portugal [Petzold et al., 2006], Italy ([Kishcha et al., 2005]), and more generally over Europe in other studies as in [Simpson et al., 1999; Querol et al., 2004b; Viana et al., 2007]. In these countries, a large number of experimental field campaigns [Clairborn et al., 1998; Gomes et al., 2003], routine measurements of particle concentrations and speciation analyses [Putaud et al., 2004], were carried out to provide several clues about the relative amount of these particles in the total budget of air quality over cities. The observed background annual average mass concentrations for particles with diameters smaller than or equal to $10 \mu \mathrm{m}$ (named PM10) for the continental Europe is 7.0 \pm 4.1 $\mu g . m^{-3}$ according [Van Dingenen et al., 2004]. The natural contribution has to be taken into account because the EU standards fix an annual mean lower than $20 \mu \mathrm{g} \cdot \mathrm{m}^{-3}$ and a maximum allowance for the number of days exceeding the daily limit value (50 $\mu \mathrm{g} . \mathrm{m}^{-3}$ ) of 7 days per year by the first of January 2010.
In an European air quality framework, modeling of dust has been mainly addressed as a transport of African dust towards Europe, [Kallos et al., 1998; Gobbi et al., 2004; Millan et al., 2005; Kallos et al., 2006]. These studies are often dedicated to climate change and dust concentration trends over the world. Model results are compared to measurements such as aerosol optical thicknesses and satellite data, using monthly averaged values. Moreover, since the most important source areas are located in Africa, China and Australia, the most important efforts are done to better describe dust emissions in these areas.

For dust emissions inside Europe, a recent study, [Vautard et al., 2005], showed that, with a very simplified approach of wind blown dust emissions, a chemistry-transport model (CTM), such as CHIMERE, is able to partly explain the lack of modeled particulate matter compared to the background values generally observed. This approach was validated statistically, meaning that using meteorological parameters such as surface humidity and wind speed, a simplified approach allows to give a more realistic view of aerosols over Europe. But this study was not designed to predict sudden and huge dust events as the one observed in Central Europe at the end of March 2007 and extensively described in [Birmili et al., 2008].

This event is a rare and invaluable opportunity to better understand and describe a natural phenomenon having a strong impact on air quality over Europe. By using new satellite observations and chemical analyses, the first goal of this paper is to confirm the hypothesis that the dust event started in Ukraine as assumed by [Birmili et al., 2008]. The second goal of this study is to evaluate whether a chemistry-transport model is able to represent the conditions leading to the observed emitted dust over Ukraine. The third goal is to evaluate the transport of such dust outbreaks. Since the rest of Europe was under "relatively low" aerosol background conditions, the dust plume exhibits a clear and important signal all along its way. This event is also a rare opportunity to estimate the impact of dust events on air quality over remote areas far from the emissions area (Ukraine). Surface measurements recorded in United Kingdom, Belgium and North of France are compared to model results. 


\section{Origin of the dust event in March 2007}

\subsection{General description}

[Burt, 2007] reported a dustfall on March 25, 2007 in the South of England and partly explained this event as a Saharan dust outbreak in the free troposphere and washed out by frontal precipitation in England. Moreover, several dust forecast model such as the NAAPS (Navy Aerosol Analysis and Prediction System) global aerosol model of the Naval Research Laboratory (NRL) in Monterey (USA) (http://www.nrlmry.navy.mil/aerosol_web), the dust regional forecast produced by the Barcelona Supercom-

puting Center (Spain)(http://salam.upc.es/DREAM), the CHIMERE-DUST model (http://euler.lmd.polytechnique.fr/dust/) and the dust forecast provided by the Tel-Aviv University Wheather Research Center (http://wind.tau.ac.il/dust8) diagnosed a Saharan dust outbreak flowing from Sahara to Europe. But [Birmili et al., 2008] showed that a dust event started in Ukraine on March 23, in the morning with huge amounts of dust blown up by a storm blowing over dry agricultural areas. Chernozems ("black soil" in Russian) in Ukraine contain a large fraction of organic compounds, and they are considered to be the most fertile lands in the world. Intensive agriculture, hydric and wind erosion have destroyed an area of $220.000 \mathrm{~km}^{2}$ in Ukraine. The number of dust storms (wind gusts above $75 \mathrm{~km} . \mathrm{h}^{-1}$ ) reaches 5 days per year in the Southern steppes ([Dolgilevich, 1997]). During these storms a large amount of telluric dust containing heavy metals, radionuclides, pesticides are transferred into the air and can be transported on the whole Europe.

As shown in [Birmili et al., 2008], many ground aerosol measurements are available over Europe during the month of March 2007, clearly demonstrating the large-scale European extent of this huge dust event. These authors presented an exhaustive description of the real event, recorded in both meteorological and particle measurements. Briefly, from March 21 [00:00] UTC to March 23 [12:00] UTC (all hours are UTC in the paper), two low pressure systems located in the Mediterranean basin and in
Northern Europe merged into a single system centered over Romania on March 23 [12:00]. At the same time, an anticyclone in Russia drives cold air mass towards central Europe. The combination of these two systems creates a East-West corridor with strong easterly winds on March 23 and 24. In the morning of March 23, the mean surface wind speeds are the highest in the South steppes of Ukraine, they exceed $15 \mathrm{~m} . \mathrm{s}^{-1}$ with friction velocities allowing dust to be blown up.

\subsection{Vertical structure of the plume}
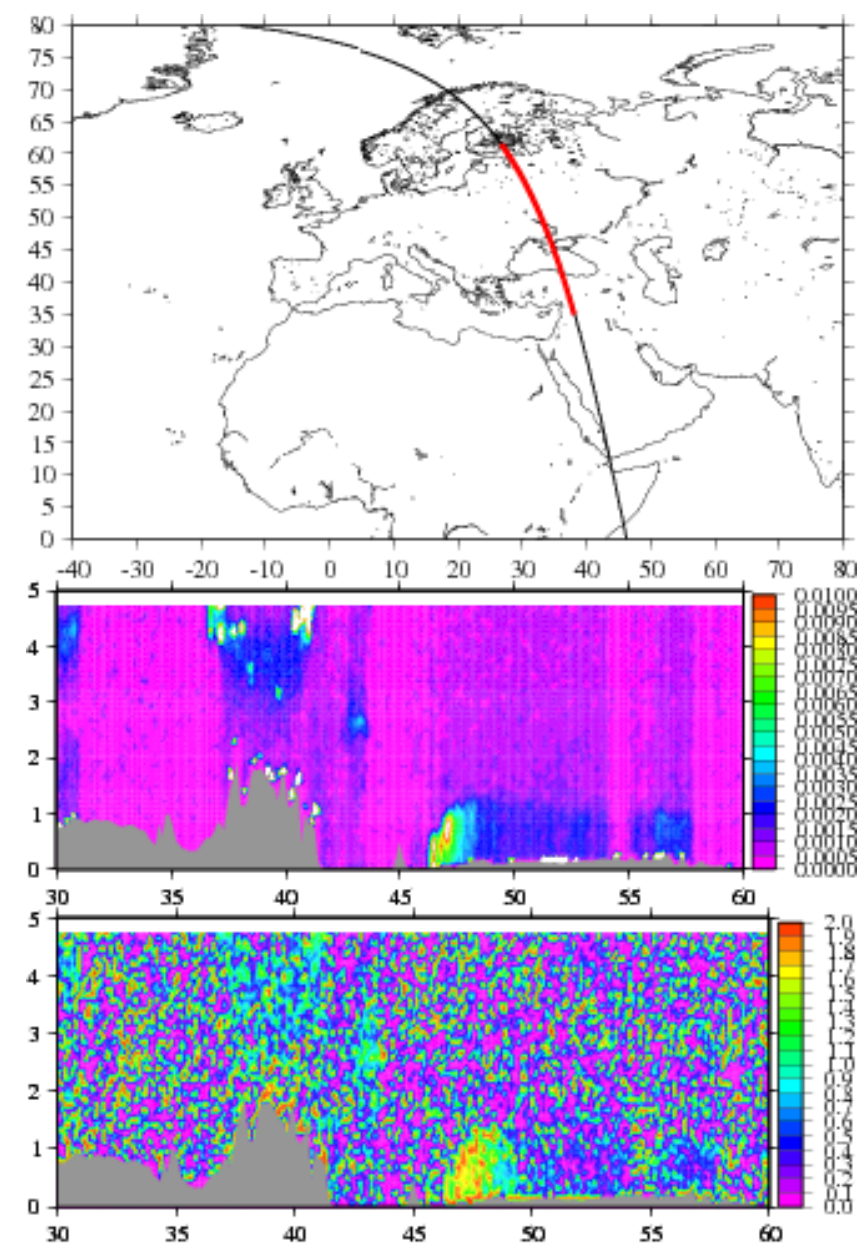

Figure 1. Vertical cross-section (Latitude-Height diagrams) of CALIOP data March 23, 2007, at about [10:50] : satellite trajectory (top), backscatter signal (middle) and color ratio (bottom)

These large scale dust patterns can be evaluated using satellite data and more specifically lidar aboard satellite such as the CALIOP lidar. It operates at 532 
and $1064 \mathrm{~nm}$ and was launched in May 2006 onboard the helio-synchroneous CALIPSO platform [Winker et al., 2008]. Here we use the total attenuated backscatter (ATB) signal from Version 1.10 Level 1 CALIOP data collected during day time at 532nm (Figure 1 - middle) and 1064nm to compute the color ratio $\mathrm{CR}=\mathrm{ATB} \_$1064/ATB 532 (Figure 1 bottom). Below $8 \mathrm{~km}$, the original horizontal resolution is $333 \mathrm{~m}$ and the vertical resolution $30 \mathrm{~m}$. To increase the signal to noise ratio, the data are averaged over $90 \mathrm{~m}$ vertically and $1 \mathrm{~km}$ horizontally. Figure 1 (middle) shows a dust outbreak in the boundary layer up to $1.2 \mathrm{~km}$ of altitude above Ukraine (around $47^{\circ} \mathrm{N}$ ) on March 23 at about [10:50]. The high value of color ratio ( $\mathrm{CR}>1.3$, Figure 1 - bottom) underlines that the particles are large compared to usual aerosols : CR is about 0.5 for urban and maritime aerosols, and 1.2 for Saharan dust [Liu et al., 2005]. The color ratio clearly shows that particles above the high topography at $38^{\circ} \mathrm{N}$ (mountains of Turkey) and the ones above Ukraine have different compositions and do not come from the same source. Above Ukraine, the depolarization ratio (not shown here) is ranging between 25 and 40\%, meaning that the particles are likely non-spherical. These satellite data confirm that a huge dust plume was developing in the boundary layer over the South of Ukraine on March 23 [10:50].

\subsection{Chemical speciation}

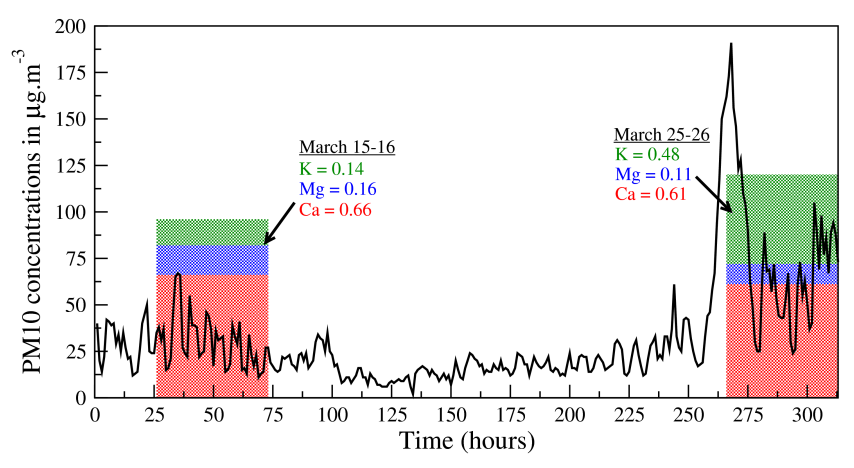

Figure 2. Time series of observed hourly PM10 concentrations recorded on March 14 [00:00] - 27 [00:00], 2007 in Gravelines (France) and chemical analyses for $\mathrm{K}^{+}, \mathrm{Ca}^{2+}, \mathrm{Mg}^{2+}$.

The time series in Figure 2 shows the dust event occurring on March 25 morning in Gravelines (North of France, Table 1). PM10 samples were collected on filters, for the March 15-16 and 25-26 periods with the latter including the dust event period in Gravelines. Water soluble potassium $\left(\mathrm{K}^{+}\right)$, calcium $\left(\mathrm{Ca}^{2+}\right)$ and magnesium $\left(\mathrm{Mg}^{2+}\right)$ contents in particles were measured by ionic chromatography. Measurements show that compared to a period without dust event (March 15-16), $\mathrm{Ca}^{2+}$ and $\mathrm{Mg}^{2+}$ concentrations during the Ukraine dust event remain low. As already reported in other studies, it is well known that Saharan dust events exhibit in Europe a large increase of $\mathrm{Ca}^{2+}$ content in measurements [Aymoz et al., 2004]. Then, the assumption of possible Saharan dust is not supported by these chemical analyses. Moreover, $\mathrm{K}^{+}$, whose content largely increased during the period of interest, is element is a natural compound highly concentrated in humus which constitutes the top layers of Ukraine chernozems. These chemical analyses confirm that this event was unlikely due to Saharan dust.

\section{General set-up of the CHIMERE model}

In this study, the V200709A version of the CHIMERE CTM over Europe is used ([Schmidt et al., 2001]; [Bessagnet et al., 2004]). The model domain covers a large part of Europe from Ireland up to Ukraine, from $10^{\circ} \mathrm{W}$ to $40^{\circ} \mathrm{E}$ and from $36^{\circ} \mathrm{N}$ to $61.5^{\circ} \mathrm{N}$ with a resolution of $1 / 2$ degree both in latitude and longitude. The vertical grid contains 20 layers from surface to $500 \mathrm{hPa}$. The dynamics and gas-phase parts of the model are described in [Schmidt et al., 2001], and improvements have successively been brought, some being described in [Vautard et al., 2003] and [Vautard et al., 2005]. The model documentation can be found on the web server http://euler.lmd.polytechnique.fr/chimere. For both ozone and PM10, the model has undergone extensive modeled aerosols intercomparisons at European and city scales ([Vautard et al., 2007; Van Loon et al., 2007; Schaap et al., 2007]). However, for mineral dust such an intercomparison has not been carried out yet.

In order to be consistent with the PREVAIR operational forecast system using MM5 and CHIMERE, 
the MM5 configuration was chosen to be the same as the one used and validated during the last three years for the daily forecast ([Honoré et al., 2008]). The MM5 vertical grid contains 32 levels ranging from surface to $10 \mathrm{hPa}$. The horizontal resolution is $60 \mathrm{~km}$ over a domain encompassing the CHIMERE domain. The MRF scheme for boundary layer physics ([Hong and Pan, 1996]) was chosen to be the most accurate for various convective situations in a forecast context. The meteorological boundary conditions as well as the nudging is performed with the six-hourly Global Forecasting System (GFS) analysis meteorological fields at $1^{o} \times 1^{o}$ resolution. The land surface and soil processes are computed with the NOAH LSM model ([Chen and Dudhia, 2001]). The physics parameterizations include the REISNER2 scheme for cloud microphysics ([Reisner et al., 1998] and the RRTM scheme for radiation ([Mlawer et al., 1997]). The duration of MM5 runs are 5 days as for CHIMERE.

In CHIMERE, the meteorological input are updated each hour. The aerosol module is that described in [Bessagnet et al., 2004]. Anthropogenic emissions are taken from the Co-operative Programme for Monitoring and Evaluation of the Longrange Transmission of Air pollutants in Europe EMEP - ([Vestreng, 2003]). Aerosol emissions feed the model species denoted as "primary particle material" (PPM), which may contain several compounds (such as black and organic carbon) coming from various anthropogenic sources. The other modeled species are sulfates, nitrates, ammonium, secondary organic aerosols, sea-salt (considered as inert here) and dust. The particle size distribution ranges from about $10 \mathrm{~nm}$ to $40 \mu \mathrm{m}$ and are distributed into 12 bins. The 12 bins used are defined between the following intervals: $0.0097,0.019,0.039,0.078,0.156$, $0.312,0.625,1.25,2.5,5,10,20$ and $40 \mu \mathrm{m}$. For small particles, and in addition to saltation and sandblasting processes (described in §5.1) CHIMERE also accounts for resuspension [Vautard et al., 2005; Loosmore, 2003].

For this case study, the CHIMERE model simulates the emissions and transport of aerosols over Europe from the March 11 [00:00] to the March 26 [00:00]. Only results on concentrations from March 21 [00:00] are analyzed in order to account for a 10 days spin-up period.

\section{Meteorological model outputs}

As described by [Birmili et al., 2008], Figure 3 shows that the model is able to calculate $10 \mathrm{~m}$ wind speed values around $15 \mathrm{~m} . \mathrm{s}^{-1}$ on March 23 [12:00] in Ukraine, with a large boundary layer height (BLH). At the meteorological MESONET station Krivyy Rih Dnipropetrovsk (Ukraine) (the closest station to the emission area which is located at $48.05^{\circ} \mathrm{N}, 33.22^{\circ} \mathrm{E}$ ), gust wind speed values were observed up to $24 \mathrm{~m} \cdot \mathrm{s}^{-1}$. In addition, the associated parameterized friction velocity $\mathrm{u}_{*}$ reflects these high wind speed and presents values potentially able to start saltation processes. Even if the mean boundary layer height (BLH) remains below $1000 \mathrm{~m}$ on March 24 [00:00], a "channel" of higher height is modeled and observed in [Birmili et al., 2008]. From South-East (Ukraine) to North-West (North of Germany), heights of more than $1500 \mathrm{~m}$ (corresponding to high values for a nighttime period) are simulated. This system persists during the next day and exhibits increasing BLH values until noon (Figure 3). Figure 4 shows a comparison between modeled values and observations at Krivyy Rih Dnipropetrovsk, for $2 \mathrm{~m}$ temperature and $10 \mathrm{~m}$ wind speed. A good agreement is shown between the model and data. Moreover, the evolution of modeled soil moisture (depth $0-10 \mathrm{~cm})$ is displayed showing a slight decrease of simulated values confirming that the period of interest becomes dry, favourable to erosion as mentioned in [Birmili et al., 2008].

\section{Modeling of European dust emissions}

\subsection{Saltation and sandblasting}

The saltation and sandblasting parameters are fully described in [Vautard et al., 2005]. Modeling dust entrainment into the atmosphere has been the subject of many studies since the work of [Bagnold, 1941]. Several detailed emission models have been proposed such as [Marticorena and Bergametti, 1995]; [Alfaro and Gomes, 2001] and [Nickovic et al., 2001]. They are currently used in transport models for sensitivity studies, analyses or forecasts as in DREAM ([Nickovic et al., 2001]), CHIMERE- 

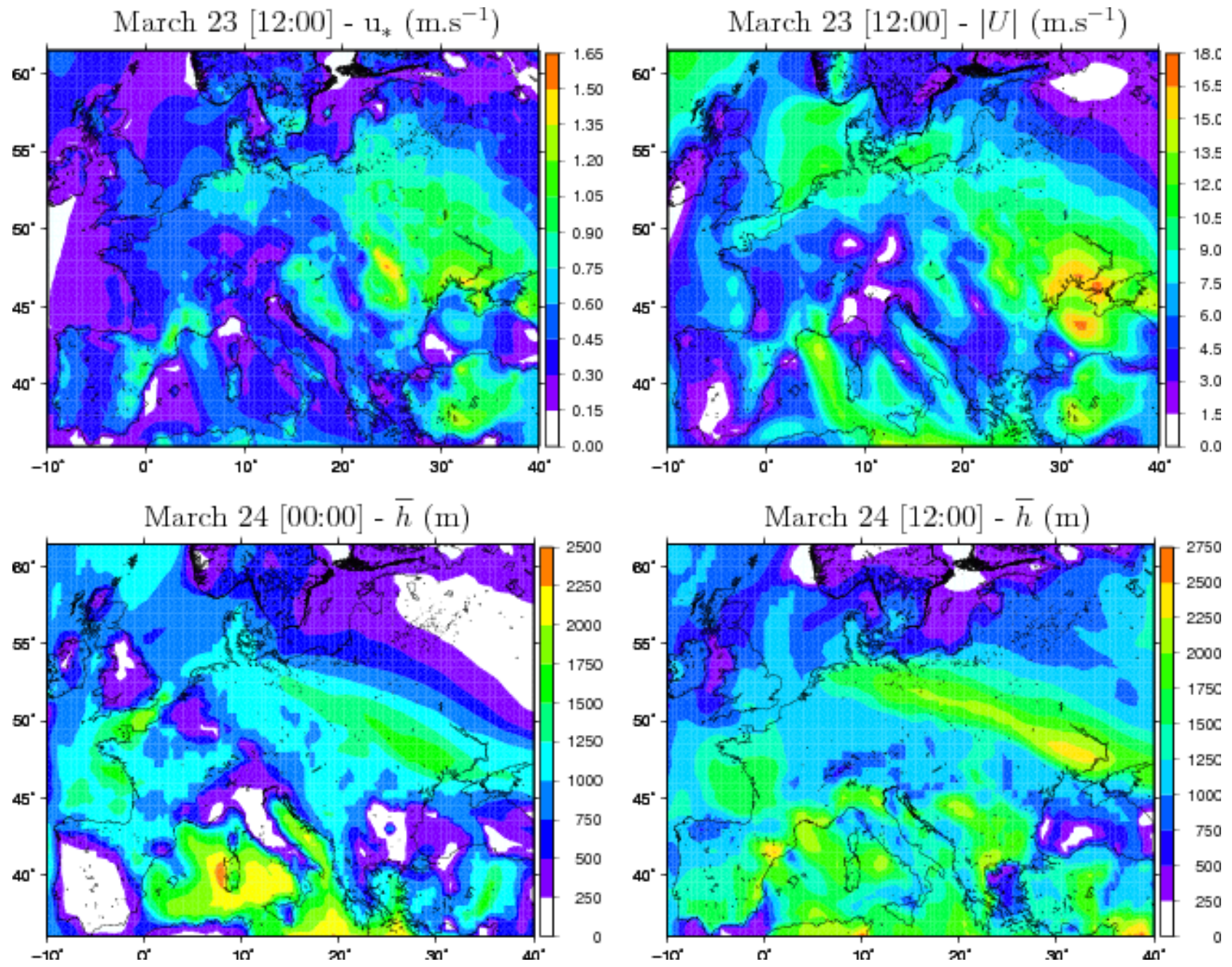

Figure 3. Model meteorological outputs : [top] friction velocity $\left(u_{*}\right)$ and horizontal $10 \mathrm{~m}$ wind velocity $(|U|)$ on March 23, 2007 [12:00], [bottom] Boundary layer height $\bar{h}$ on March 24 [00:00] and [12:00], 2007.

DUST ([Forêt et al., 2006], [Menut et al., 2005] and [Menut et al., 2007]), among others. In this study, we use an improved version of the [Vautard et al., 2005] scheme. This scheme originates from that of [Marticorena and Bergametti, 1995]. The sandblasting flux $F_{v}$ is expressed as the product of the saltation dust flux $F_{h}$ and $\alpha$, the sandblasting efficiency: $F_{v}=\alpha \times F_{h}$. This latter is constant and taken as $\alpha=5 \cdot 10^{-5} \mathrm{~m}^{-1}$ an order of magnitude obtained from the measurements, over Northern Spain and Niger, of [Gomes et al., 2003]. The saltation flux is expressed as:

$$
F_{h}=C u_{* s}\left(u_{* s}^{2}-u_{* t}^{2}\right)
$$

where $u_{* s}$ denotes the saltation friction velocity, $u_{* t}$ the threshold friction velocity and $C$ is a coefficient that depends on several surface factors. The saltation friction velocity $u_{* s}$ corresponds to that encountered on erodible parcels of the model grid cell, usually smoother than typical vegetated surfaces found in Europe. It is calculated by using the $10 \mathrm{~m}$ wind field, a constant saltation roughness length of $5.10^{-4} \mathrm{~m}$ and the assumption of neutral stability as in most previous studies. In order to keep the formulation simple, the threshold friction velocity is assumed to depend only on gravimetric soil moisture $w$ and follows the [Fecan et al., 1999] formulation. 

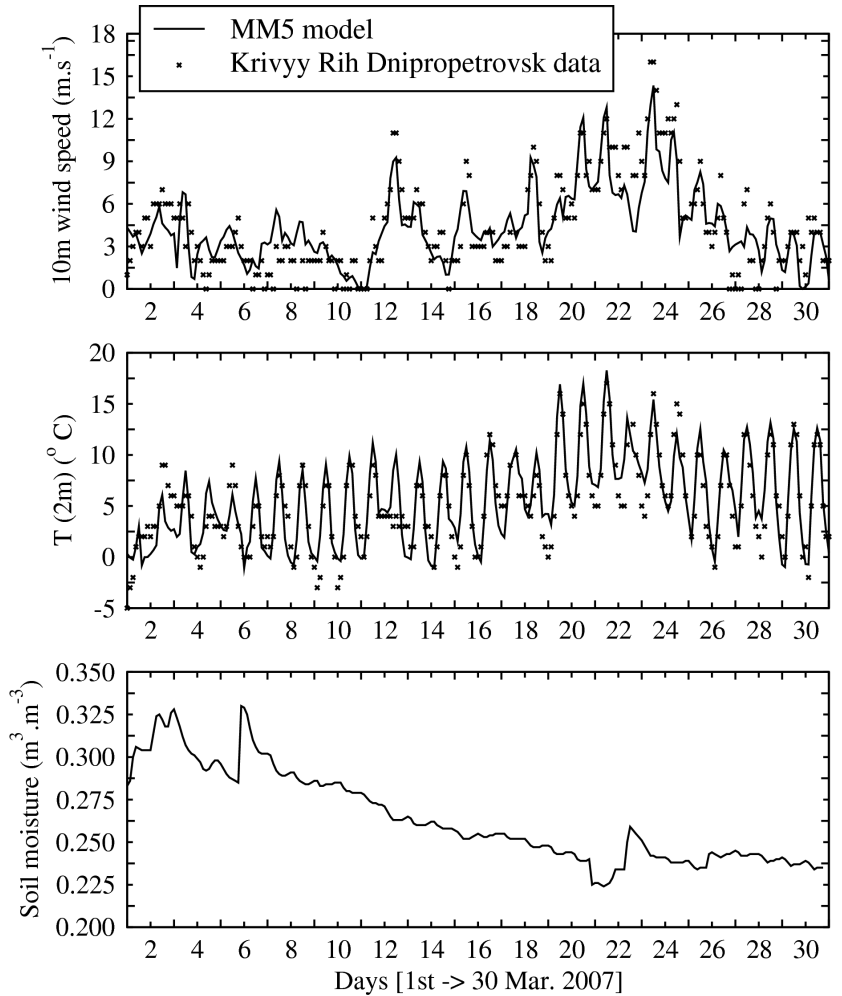

Figure 4. Time series of MM5 meteorological model outputs for the cell corresponding to the most intense source emission area in Ukraine. Cross symbols represent data issued from the closest station Krivyy Rih Dnipropetrovsk (Ukraine).

\subsection{Model improvements for this study}

For the present study, specific improvements were performed on the soil description and the calculation of the saltation over Europe. To our knowledge, this is the first study dealing with the implementation of chernozemic soils in a chemistry-transport model over Europe. In general, the problem of dust emissions estimation is that two mandatory parameters are required without any measurements being available: (i) the emissions magnitude, and, (ii) the dust size distribution. For instance, over Western Africa, the lack of concentrations measurements is a major limitation. Parameterizations are optimized after long term simulations and using statistical adjustements with comparisons to aerosol optical thicknesses (with the AERONET photometers network for example, [Holben et al., 2001]). This approach is suitable in case of long-term global modeling when

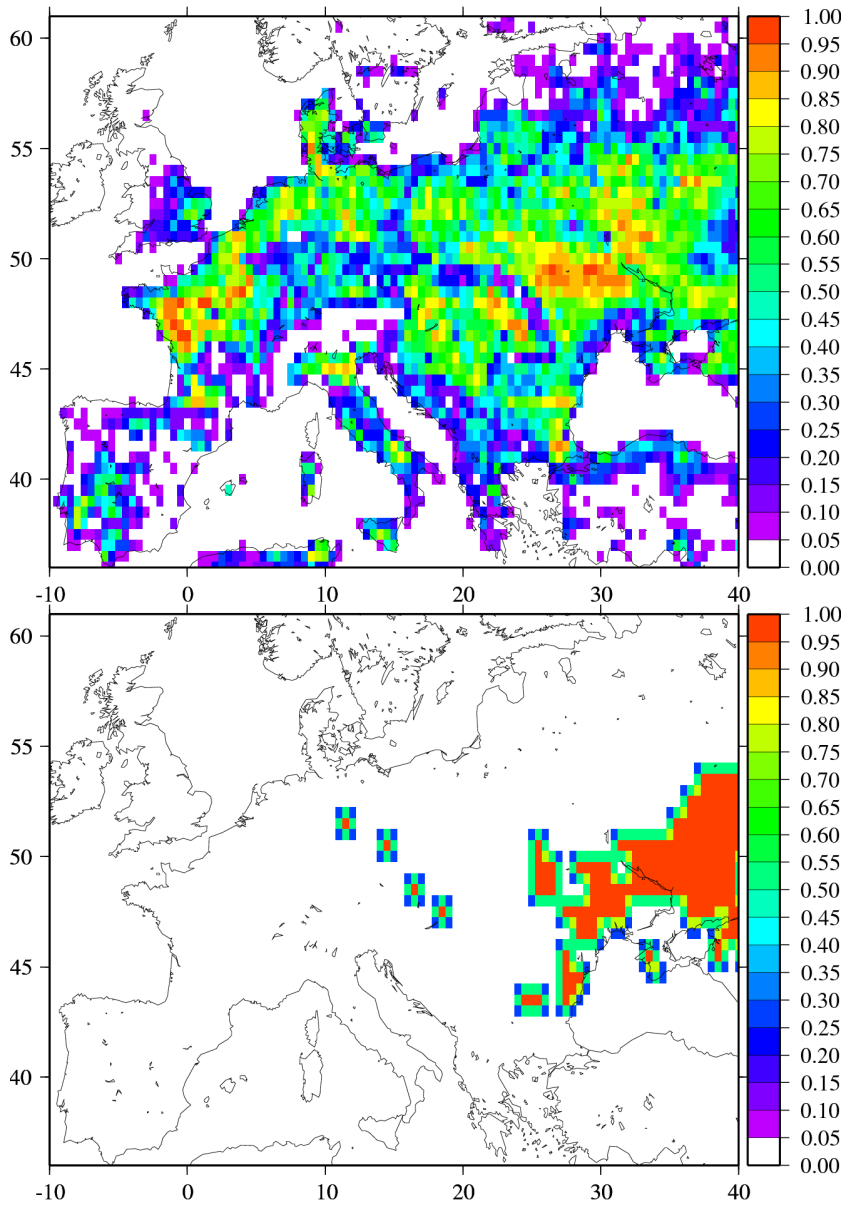

Figure 5. Fraction of [top] cropland and [bottom] chernozemic soil in the simulation domain

only seasonal tendencies are studied.

A first improvement to the [Vautard et al., 2005] scheme, is the dependence of the saltation parameters to the model surface characteristics over land, assumed constant in that study. In the present work, this aspect is refined and dust saltation only for cropland is affected representing the whole contribution of arable surface. For instance, this change eliminates unrealistic dust fluxes diagnosed over mountainous areas.

A second improvement concerns the soil description. As described in [Dolgilevich, 1997], chernozemic soils cover a large part of Ukraine arable lands. In order to specifically work on this episode, and following analyses of [Birmili et al., 2008], additional information about these soils was added in the model landuse. Based on [Zobler, 1986], [Webb et al., 2000] gives a set of 108 soil types at a $1 / 2$ degree resolution all over the world. Four types 

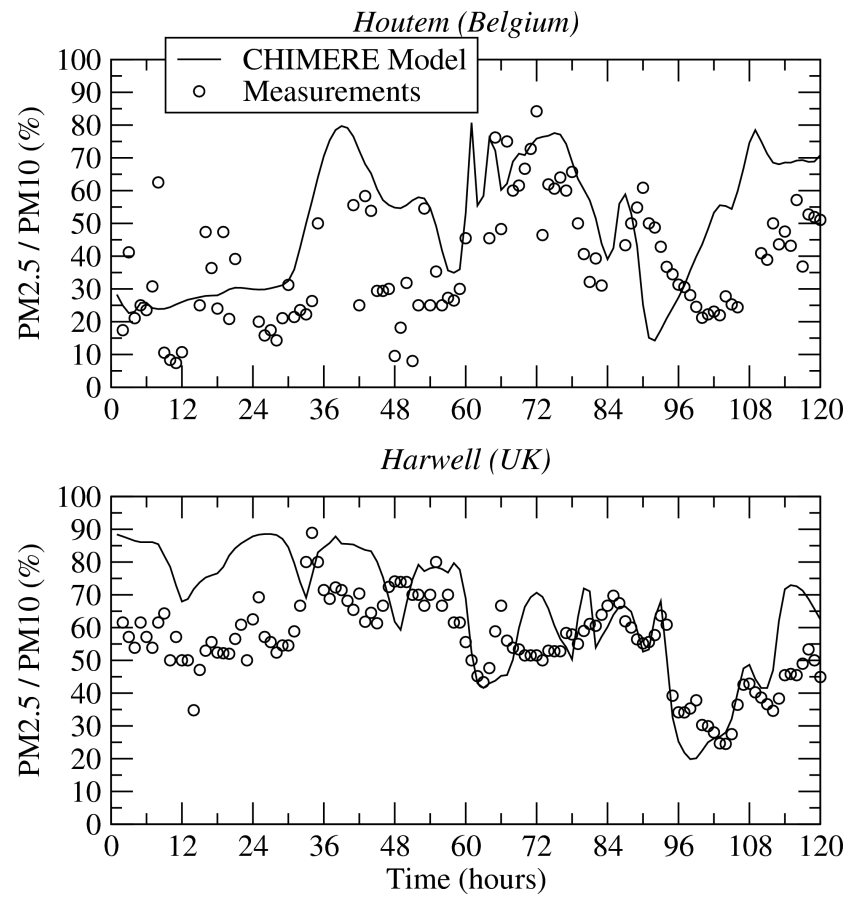

Figure 6. Modeled and measured PM2.5/PM10 concentration ratio in Houtem (Belgium) and Harwell (United Kingdom) from March 21 [00:00] to March 26 [00:00], 2007.

of chernozems are identified (glossic, haplic, calcic and luvic), and are aggregated into one soil type representative of chernozemic soils. Figure 5 (bottom) displays the fraction of chernozems over the CHIMERE domain used in this study and Figure 5 (top) the fraction of crop lands after [Hansen et al., 2000]. Thus, the second improvement is to have a real distinction between non-chernozemic and chernozemic crop lands in the model.

Finally, a third improvement concerns the size distribution of emissions. In our case, we have two types of input information to constrain the size distribution all along the plume (from the emissions to the most remote areas):

- the size distribution of emitted dust after measurement campaigns over Europe as described in $[\mathrm{Al}$ faro and Gomes, 2001]. This leads to mass median diameters for three emissions mode that is $D_{p}=1.5,6.7$ and $14.2 \mu \mathrm{m}$;

- the PM2.5/PM10 concentrations ratio after surface measurements recorded in Houtem (Belgium) and Harwell (UK) (see Table 1 for coordinates).
Using these information, we adjust the size distribution of the emissions. This distribution is assumed to be constant during the whole period. We checked after long-range transport the modeled concentrations. The comparison of measurements versus model for the PM2.5/PM10 ratio is displayed in Figure 6. Two important features have to be mentioned : (i) the general variability of modeled PM2.5/PM10 ratio is consistent with measurements, (ii) the sudden decrease near the hour 96 (corresponding to March 24 [00:00], time of the dust plume outbreak over these two remote stations) is observed and simulated by the model. Figure 6 displays a large contribution (about $75 \%$ ) of coarse particles (i.e for particles with a diameter $>2.5 \mu \mathrm{m}$ ) in the PM budget. The resulting distribution over the 12 bins is displayed in Figure 7. This corresponds to the best adjustment for the model in this specific case. This kind of distribution is consistent with previously well known distribution such as values recorded over North America by [Watson and Chow, 2000]. Moreover, the presence of very large particles is consistent with the CALIOP observations discussed in $\S 2.2$.

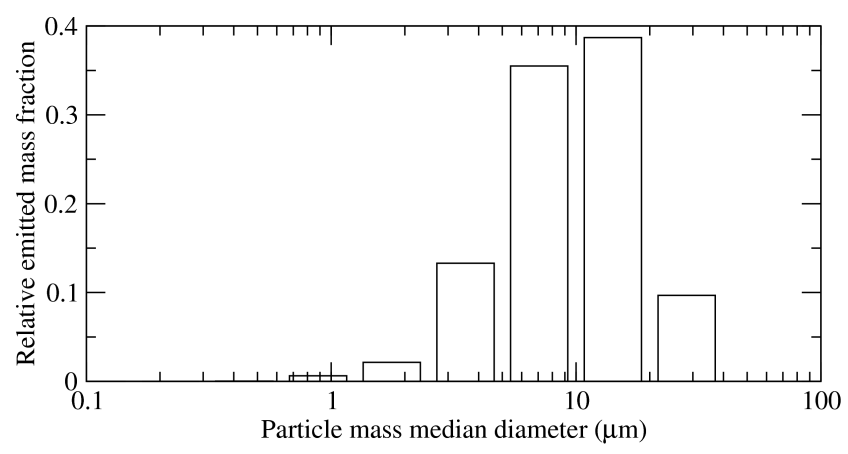

Figure 7. Histogram of the relative mass fraction applied to dust emissions implemented in CHIMERE.

Another validation step is to estimate whether this distribution is realistic, by using measurements between the emissions area in Eastern Europe (Ukraine) and the end of the plume over land (i.e Belgium and UK). Model and measurement size distributions are compared at the Melpitz station $\left(51.53^{\circ} \mathrm{N}\right.$ and $12.93^{\circ} \mathrm{E}$, Germany), located on the way of the plume. Figure 8 presents the size distribution of modeled PM concentrations for dust only (grey bars) and total PM. These values are extracted 
from the model cell corresponding to the Melpitz station. On March 22, 2007, there is no dust arriving in Melpitz and the size distribution has a peak centered around $0.3 \mu \mathrm{m}$, representative of usual anthropogenic pollution. On March 23, 2007, a first contribution of dust is modeled but without inducing a significant change in the shape of the concentration distribution. On March 24 and 25 dust dominates the total mass of the modeled PM and shifts the peak of the distribution to the coarse particles of around 3 $\mu m$, the same value as observed in [Birmili et al., 2008].
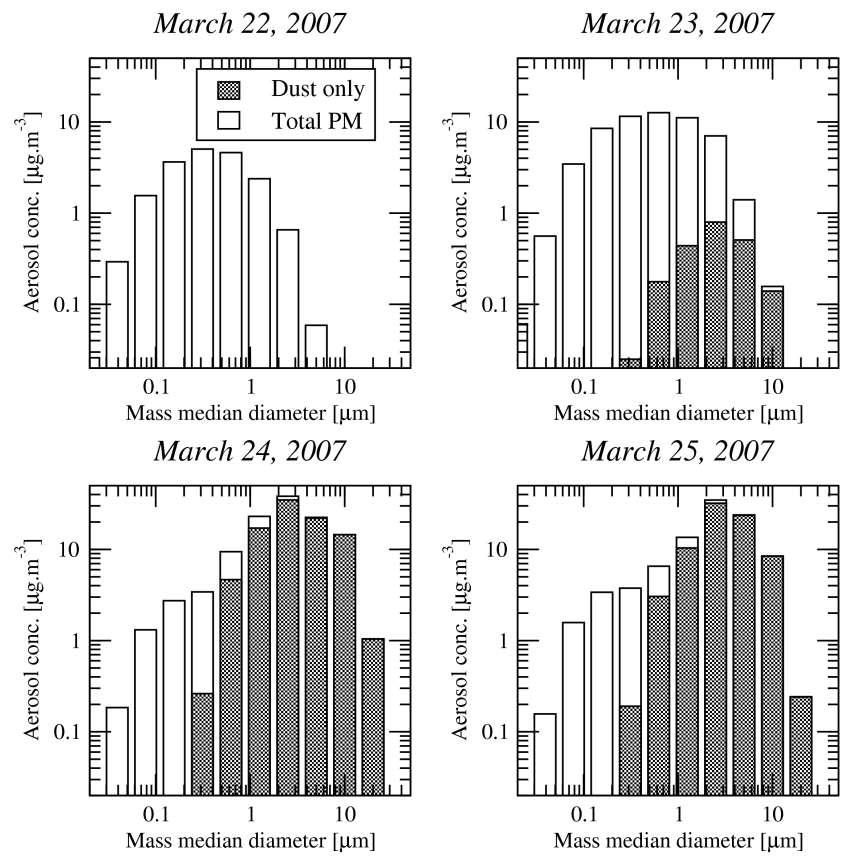

Figure 8. Particle size-segregated concentrations simulated by CHIMERE in Melpitz surface station on March 22-25, 2007 (daily mean values).

Accounting for the three improvements described above, surface dust emissions are calculated on an hourly base, an example of results is displayed in Figure 9. The largest fluxes are limited to the Ukraine area. In this section, it has been demonstrated that after some adaptations to realistic soils, the model is able to calculate a huge and sporadic dust event over a typical Europe surface type. We now turn to the hypothesis that the corresponding dust plume may have been transported farther than over the Slovakia, Poland and Germany stations as described in [Birmili et al., 2008].

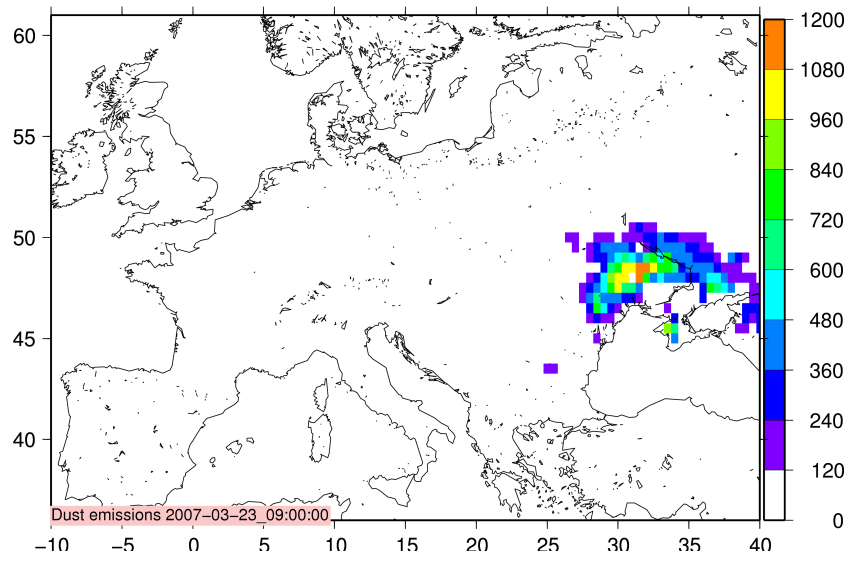

Figure 9. Dust emissions (molecules.cm ${ }^{-2} \cdot s^{-1} \times$ 10-11) on March 23 [09:00], 2007 with improvements in the cropland landuse fraction and chernozemic soils characteristics.

\section{Results}

Two simulations were carried out in order to evaluate the ability of the model to reproduce observed remote surface concentrations. The first simulation used the CHIMERE model with all processes (gas and aerosols) except the dust emissions and transport. The second simulation is the same but adding dust emissions and transport. Hourly time series are used to compare the model results with available observational data.

\subsection{Surface maps of PM concentrations}

The surface concentrations results are presented in Figure 10, with nine maps, every six hours from March 23 [12:00] to 25 [12:00]. The main dust event starts on March 23 [12:00], 2007.

It is spatially limited to the Ukraine area and modeled concentrations reach maximum values $\approx$ $1000 \mu \mathrm{g} \cdot \mathrm{m}^{-3}$. The model slightly understimates the maximum amplitude where observations up to 1400 $\mu \mathrm{g} . \mathrm{m}^{-3}$ are shown in [Birmili et al., 2008]. Over surface stations in Europe, the model fairly reproduces the highest concentrations at the right moment few hours later in remote areas.

The plume then moves towards Germany (Figure 10) from March 23 [18:00] to March 24 [06:00]. Starting from the 24 [12:00], the plume splits into two parts: a long-range transported plume travelling towards Belgium, United Kingdom (UK) and North 
of France. A second spot is observed corresponding to new and moderate emissions in Ukraine. At the end of the episode (March 25 [12:00]), and after two diurnal cycles, a long plume stretches from Ukraine to Belgium, with two additional high concentrations spots: one over the Western part of the UK and France, and one over the emissions area. For this episode, the model is consistent with the surface measurements values presented in [Birmili et al., 2008]. It also provides information over the whole Europe showing that surface concentrations of more than $120 \mu \mathrm{g} . \mathrm{m}^{-3}$ are due to Ukrainian dust and may be observed far from the source few hours later in remote area i.e. the Western part of Europe.

\subsection{Analysis of vertical cross-section}

Figure 11 presents vertical cross-sections of dust concentrations focused on the period of the largest emissions event and the transport of the plume to the Western part of the domain. The plume vertical extension reaches $1800 \mathrm{~m}$ at the beginning of the episode, dust being injected in the boundary layer and well-mixed around [12:00] due to the strong turbulence induced by the strong horizontal pressure gradient. From East to West, the dust plume is transported and the vertical structure becomes less homogeneous: several maxima are modeled within the plume (e.g. March 24 [06:00]). At the end of the period, two distinct plumes are observed, one over Northern Germany with a low thickness on March 24 [00:00] (1200m height) and a most intense one in Ukraine on March 24 [12:00] (more than 2000m height). Figure 12 shows that the model is able to reproduce the vertical structure of the plume observed and described in [Birmili et al., 2008] with the correct vertical extension around $1800 \mathrm{~m}$ at noon for each observed day.

\subsection{Modeled time series versus measurements}

Far from the source in Houtem (Belgium) and Harwell (United Kingdom) (see coordinates in Table 1), the model is able to reproduce the magnitude of the concentrations as well as the time of the dust peak. By comparing the two simulations, the net contribution of the dust event to air quality in the Belgium and United Kingdom is rather clear. While background particulate matter concen-

\begin{tabular}{lrrr}
\hline Station & Country & Latitude $\left({ }^{\circ} \mathrm{N}\right)$ & Longitude $\left({ }^{\circ} \mathrm{E}\right)$ \\
\hline Houtem (Ho) & Belgium & 51.02 & 2.58 \\
Gravelines (Gr) & France & 50.97 & 2.14 \\
Prunay (Pr) & France & 48.86 & 1.68 \\
Foret de Brotonne (Br) & France & 49.41 & 0.69 \\
Phare d'Ailly (Ai) & France & 49.92 & 0.96 \\
Canterbury (Ca) & U.K. & 51.28 & 1.08 \\
Lough Navar (Lo) & U.K. & 54.43 & -7.90 \\
Southampton (So) & U.K. & 50.90 & -1.40 \\
Bolton (Bo) & U.K. & 53.58 & -2.43 \\
Harwell (Ha) & U.K. & 51.57 & -1.32 \\
\hline
\end{tabular}

Table 1. Names and coordinates of stations presented in Figure 2, Figure 6, Figure 10 and Figure 12.

trations of $\approx 30 \mu \mathrm{g} \cdot \mathrm{m}^{-3}$ is calculated by the model, the dust event contributes to an additional concentration reaching 120 to $180 \mu \mathrm{g} . \mathrm{m}^{-3}$, mainly originating from Ukraine. It is noteworthy that these levels largely exceeded the EU standard of $50 \mu \mathrm{g} . \mathrm{m}^{-3}$ (daily mean value), only because of dust emissions.

Figure 12 shows a more detailed comparison of modeled versus measured surface concentrations for the reference simulation with all particles (solid line) and for the simulation without dust (dashed line). This highlights the strong impact of this episode onto local surface measurements very far from the emissions area. All time-series displayed in Figure 12 correspond to sites in Belgium, United Kingdom and France with coordinates reported in Table 1. The first part of the time period, i.e. hours ranging from March 21 [00:00] to 24 [00:00] showed background PM concentrations fairly well reproduced, with values around $30 \mu \mathrm{g} \cdot \mathrm{m}^{-3}$. On March 25 [00:00], the plume is first observed over Belgium, followed by UK and North of France. The maximum values reach more than $200 \mu \mathrm{g} \cdot \mathrm{m}^{-3}$ in the rural site Phare d'Ailly. The arrival time of the plume is slighty simulated in advance by the model. This may be due to the uncertainties in modeled surface wind speed and by the cumulative effect of two days of particulate matter to transport across Europe. Even if the station of Lough Navar is the most remote site in this study, the model succeeds in catching the local PM maximum late in the afternoon with values twice higher than the background values. 

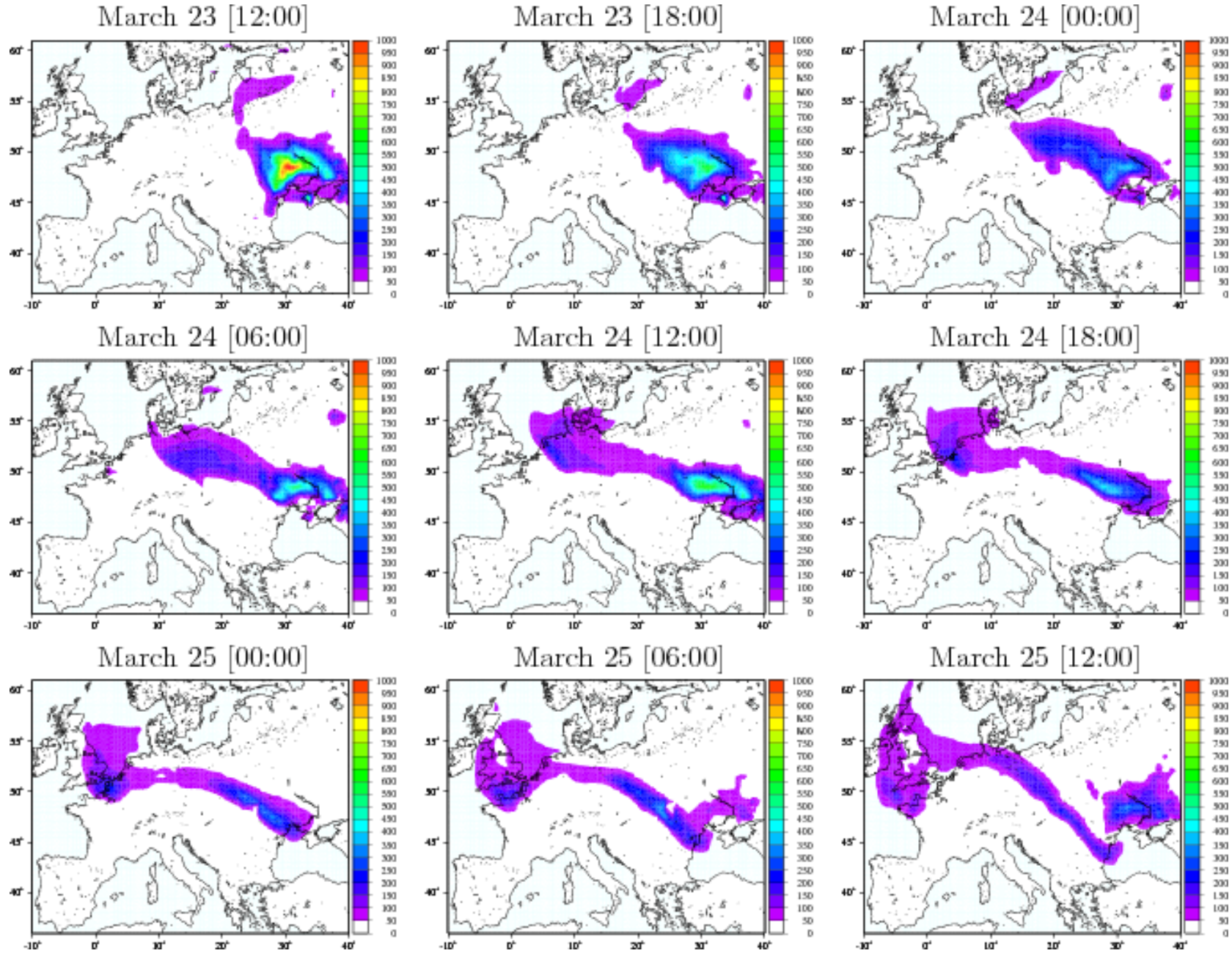

Figure 10. Surface PM10 concentrations $\left(\mu \mathrm{g} . \mathrm{m}^{-3}\right)$ simulated by CHIMERE from March 23 [12:00] to 25 [12:00], 2007 (see Table 1 for the names of the stations).

\section{Conclusion}

In March 2007, an exceptional dust emission event was observed over central Europe. Surface observations showed that the episode coming from Eastern Europe induced high dust concentrations transport until Germany. The assumption of a dust plume originating from Ukraine as described in a previous study is confirmed in this work thanks to CALIOP/CALIPSO data and a chemical analysis. This episode stands as an opportunity to evaluate a dust emission and transport model. We evaluated the CHIMERE chemistry-transport model, in similar versions as described in previous articles, but with an improved dust emission scheme, taking into account landuse and chernozemic soils in more de- tails. The dust scheme was adapted to better represent the dust size distribution at emission by comparisons with surface data after transport (based on PM2.5/PM10 ratios). By optimizing a few parameters, the model is able to successfully reproduce the PM10 concentrations amplitude, spatial pattern, and aerosol size distribution, very far (a few thousand kilometres) from the source. Over Western Europe the model reproduces the observed PM concentration peaks up to $200 \mu \mathrm{g} \cdot \mathrm{m}^{-3}$ with a large contribution up to $170 \mu \mathrm{g} \cdot \mathrm{m}^{-3}$ of Ukraine dust.

Using this new CHIMERE model version, the potential impact of a such an episode on the surface PM concentrations over the whole Europe was evaluated. The starting time of the dust emission was correctly simulated showing that the MM5 meteoro- 

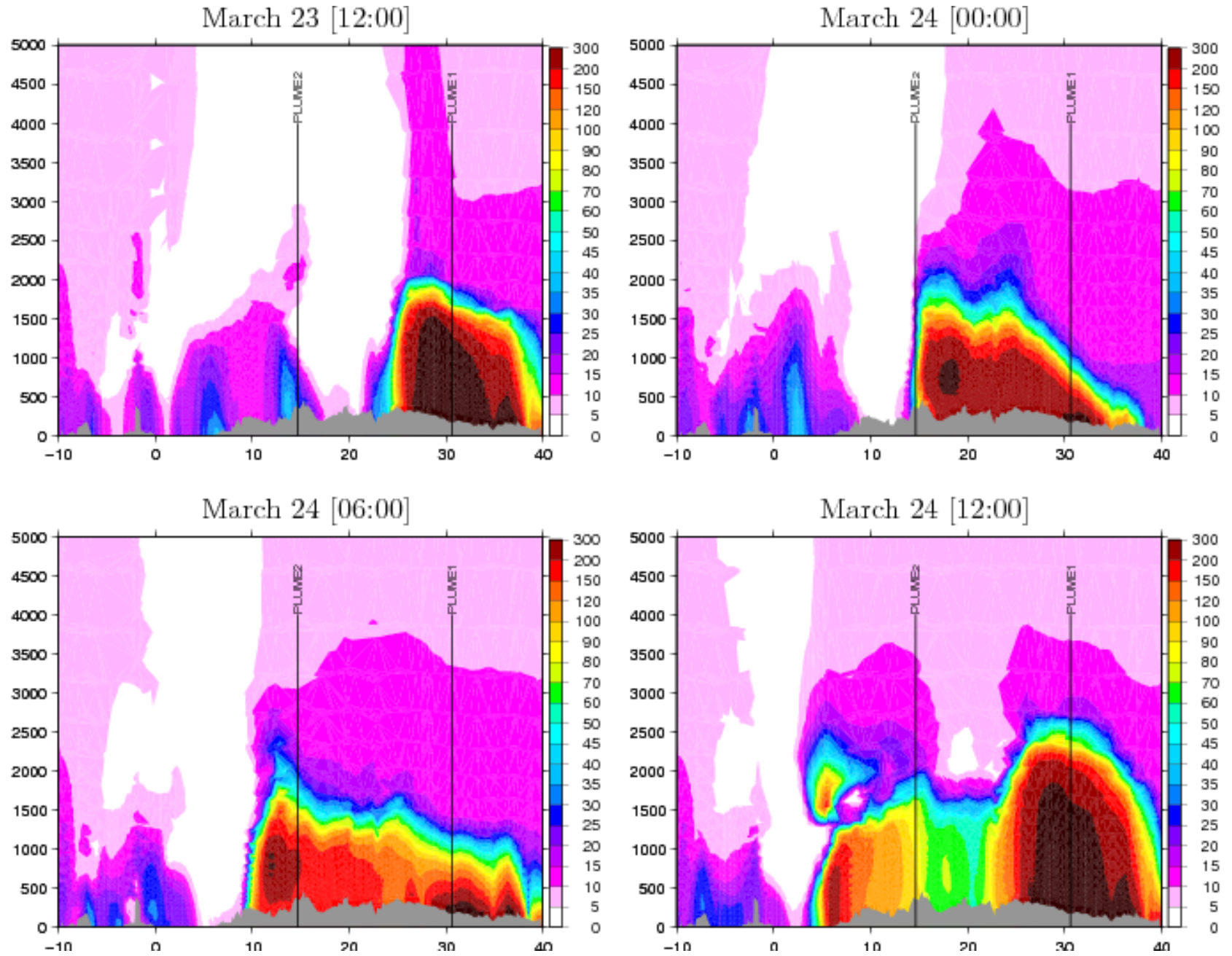

Figure 11. Vertical cross-section (Longitude-Height diagrams) of PM10 concentrations $\left(\mu g . \mathrm{m}^{-3}\right)$ along the plume (straight line passing through PLUME1 and PLUME2). The two arbitrary points named PLUME1 $\left(30.6^{\circ} \mathrm{E}-48.7^{\circ} \mathrm{N}\right)$ and PLUME2 $\left(14.6^{\circ} \mathrm{E}-51.0^{\circ} \mathrm{N}\right)$ represent respectively the emission area and a point located over the plume trajectory. Color scale stops at $300 \mu \mathrm{g} . \mathrm{m}^{-3}$, even if some very important values are calculated.

logical model catches well the specific wind speed values induced by the synoptic meteorological situation. Additional measurements were used and surface concentrations were compared over Belgium, UK and France. The model correctly predicts the peak values over all stations. This includes stations where the plume was not very intense proving that the surface extension of the plume is fairly reproduced. The vertical structure was shown to be complex with a well-mixed boundary layer and dust concentrations with high values from surface to $1800 \mathrm{~m}$ far from the emissions area. Finally, we showed that using a size distribution of twelve bins, the model is able to correctly reproduce the complex evolution of the relative part of soil dust in the particle size distribution, from dust free to loaded atmosphere. The model showed a shift from 0.3 to $3 \mu \mathrm{m}$ in the aerosol distribution consistent with measurements in Melpitz.

This kind of event has been rarely observed, and it would be interesting to diagnose its frequency. It is not clear whether other important dust events could be initiated from other regions in Europe. However, since they are probably of minor magnitude they are hardly detectable from the aerosol background. Improvements on natural particulate emissions in mod- 

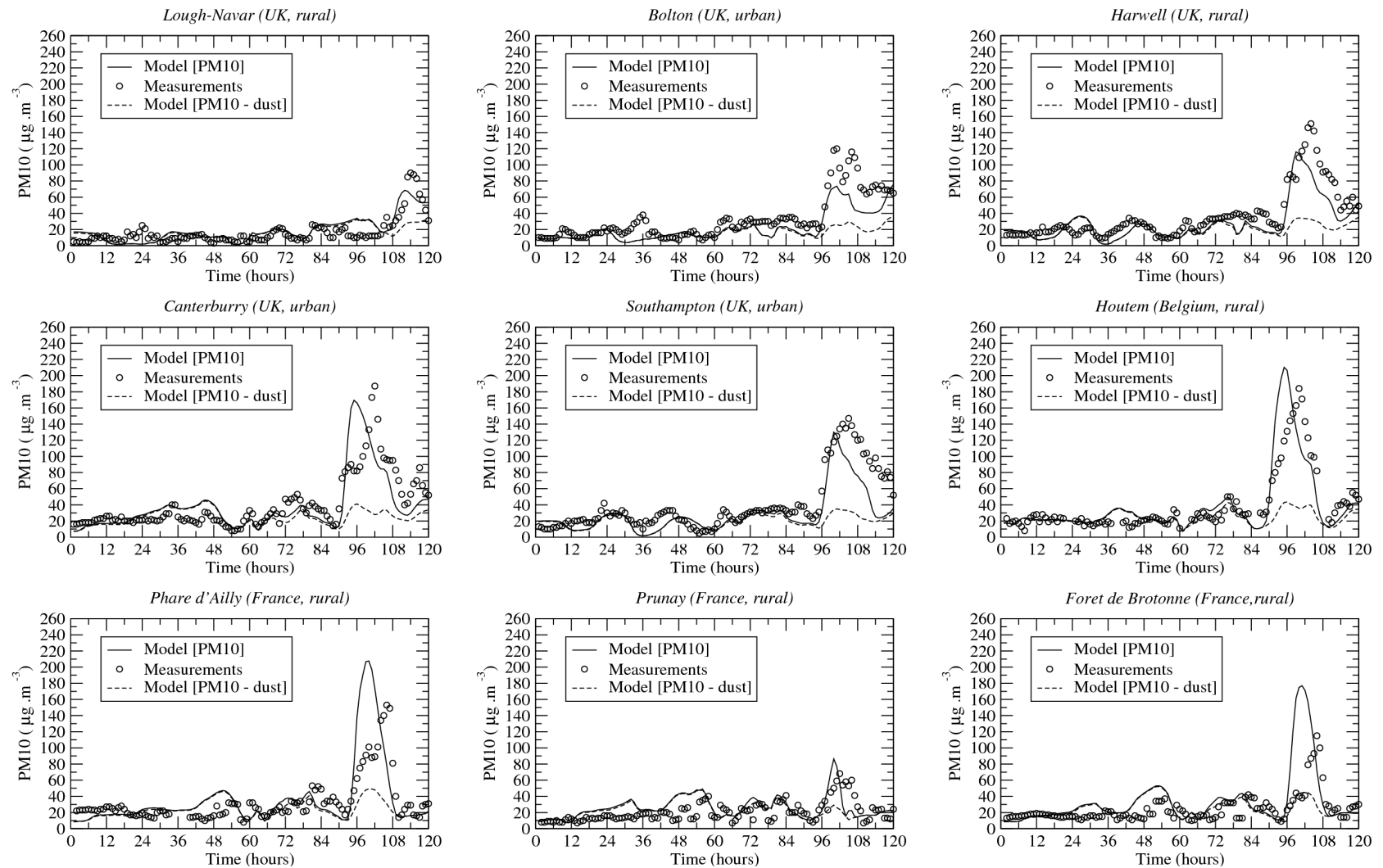

Figure 12. Time series of PM10 concentrations for nine selected sites corresponding to representative PM10 surface stations in United Kingdom, Belgium and France. The time series represent (i) the surface PM10 measurements (circles), (ii) the simulated surface PM10 without the Ukrainian dust emissions (dashed line), (iii) the simulated surface PM10 with the Ukrainian dust emissions (solid line) for the period from March 21 [00:00] to 26 [00:00], 2007.

els are required to better simulate these phenomena. This is mandatory to better predict PM10 concentrations in Europe and understand the role of soil particles in regional air quality.

\section{Acknowledgments.}

We acknowledge Dr Andy DELCLOO for providing us additional measurements issued from the Royal Meteorological Institute of Belgium as well as the UK air quality network. We also acknowledge Dr Larry OOLMAN (University of Wyoming) for providing us meteorological data, including the Krivyy Rih Dnipropetrovsk (Ukraine) measurements used in this paper. Thierry WATTIAUX is acknowledged for his technical support on computer ressources at INERIS. NASA, CNES, ICARE and Climserv are acknowledged for giving access to CALIOP/CALIPSO data. Acknowledgements to the BASTER database, managed by ADEME, enabling us to extract surface concentrations data over France. The me- teorological data were provided by the Data Support Section of the Computational and Information Systems Laboratory at the National Center for Atmospheric Research. NCAR is supported by grants from the United-States National Science Foundation. This work was partly funded by the French Ministry in charge of Ecology (MEDAD).

\section{References}

Alastuey, A., et al. (2005), Characterisation of TSP and PM2.5 at Izana and Sta. Cruz de Tenerife (Canary Islands, Spain) during a Saharan Dust Episode (July 2002), Atmos. Environ., 39, 4715-4728.

Alfaro, S. C., and L. Gomes (2001), Modeling mineral aerosol production by wind erosion: Emission intensities and aerosol size distribution in source areas, $J$. Geophys. Res., 106, 18,075-18,084.

Andreae, M., and P. Crutzen (1997), Atmospheric 
aerosols: biogeochemical sources and role in atmospheric chemistry, Science, 276, 1052-1058.

Ansmann, A., et al. (2007), Long-range transport of saharan dust to northern Europe: The 11-16 october 2001 outbreak observed with earlinet, J. Geophys. Res., 108, D24, doi:10.1029/2003JD003757.

Artinano, B., P. Salvador, G. A. Diana, X. Querol, and A. Alastuey (2003), Anthropogenic and natural influence on the PM10 and PM2.5 aerosol in Madrid (Spain). Analysis of high concentration episodes, Environmental Pollution, 125, 453-465.

Aymoz, G., J.-L. Jaffrezo, V. Jacob, A. Colomb, and C. George (2004), Evolution of inorganic components of aerosol during a saharan dust episode observed in the french alps, Atmospheric Chemistry Physics, 4, 2499-2512.

Bagnold, R. (1941), The physics of blown sand and desert dunes, Methuen and Co. Ltd. London.

Bessagnet, B., A. Hodzic, R. Vautard, M. Beekmann, S. Cheinet, C. Honoré, C. Liousse, and L. Rouil (2004), Aerosol modeling with CHIMERE: preliminary evaluation at the continental scale, Atmos. Environ., 38, 2803-2817.

Birmili, W., et al. (2008), A case of extreme particultate matter concentrations over Central Europe caused by dust emitted over the southern Ukraine, Atmos. Chem. Phys., 8, 997-1016.

Burt, S. (2007), The dustfall of 24/25 march 2007 over southern england - reply by stephen burt, Weather, 90 , doi:10.1002.

Chen, F., and J. Dudhia (2001), Coupling an advanced land-surface/hydrology model with the penn state NCARMM5 modeling system. part i: Model implementation and sensitivity, Mon. Wea. Rev., 129, 569585 .

Clairborn, C., B. Lamb, A. Miller, J. Beseda, B. Clode, J. Vaughan, L. Kang, and C. Newvine (1998), Regional measurements and modelling of windblown agricultural dust: the Columbia Plateau PM10 program, Journal of Geophysical Research, 103, 753-767.

Dolgilevich, M. J. (1997), Extent and Severity of Wind Erosion in the Ukraine, International Symposium on Wind Erosion, Kansas State University, Manhattan, KA, USA.

Escudero, M., X. Querol, A. Avila, and E. Cuevas (2007a), Origin of the exceedances of the European daily PM limit value in regional background areas of Spain, Atmos. Environ., 41, 730-744.
Escudero, M., X. Querol, J. Pey, A. Alastuey, N. Perez, F. Ferreira, S. Alonso, S. Rodriguez, and E. Cuevas (2007b), A methodology for the quantification of the net African dust load in air quality monitoring networks, Atmos. Environ., 41, 5516-5524.

Fecan, F., B. Marticorena, and G. Bergametti (1999), Parameterization of the increase of aeolian erosion threshold wind friction velocity due to soil moisture for arid and semi-arid areas, Annals of Geophysics, 17, 149-157.

Forêt, G., G. Bergametti, F. Dulac, and L. Menut (2006), An optimized particle size bin scheme for modeling mineral dust aerosol, J. Geophys. Res., 111, D17,310, doi:10.1029/2005JD006797.

Ginoux, P., J. M. Prospero, O. Torres, and M. Chin (2004), Long-term simulation of global dust distribution with the GOCART model: correlation with North Atlantic oscillation, Environ. Modelling and Software, 19, 113-128.

Gobbi, G., F. Barnaba, and L. Ammannato (2004), The vertical distribution of aerosols, saharan dust and cirrus clouds in rome (italy) in the year 2001, Atmos. Chem. Phys., 4, 351-359.

Gomes, L., J. L. Rajot, S. C. Alfaro, and A. Gaudichet (2003), Validation of a dust production model from measurements performed in semi-arid agricultural areas of Spain and Niger, Catena, 52, 257-271.

Hansen, M., R. DeFries, J. Townshend, and R. Sohlberg (2000), Global land cover classification at $1 \mathrm{~km}$ resolution using a decision tree classifier, International Journal of Remote Sensing, 21, 1331-1365.

Holben, B., et al. (2001), An emerging ground-based aerosol climatology: Aerosol Optical Depth from AERONET, J. Geophys. Res., 106, 12,067-12,097.

Hong, S.-Y., and H.-L. Pan (1996), Non local boundary layer vertical diffusion in a medium-range forecast model, Mon. Wea. Rev., 124, 2322-2339.

Honoré, C., et al. (2008), Predictability of European air quality: The assessment of three years of operational forecasts and analyses by the PREV'AIR system, $J$. Geophys. Res., 113, doi:10.1029/2007JD008761.

Kallos, G., V. Kotroni, K. Lagouvardos, and A. Papadopoulos (1998), On the long-range transport of air pollutants from Europe to africa, Geophys. Res. Lett ., 25.

Kallos, G., A. Papadopoulos, P. Katsafados, and S. Nickovic (2006), Transatlantic saharan dust transport: Model simulation and results, J. Geophys. Res., 111, doi:10.1029/2005JD006207. 
Kishcha, P., F. Barnaba, G. P. Gobbi, P. Alpert, A. Shtivelman, S. O. Krichak, and J. H. Joseph (2005), Vertical distribution of Saharan dust over Rome (Italy): Comparison between 3-year model predictions and lidar soundings, J. Geophys. Res., 110, doi:10.1029/2004JD005480.

Liu, Z., A. Omar, Y. Hu, M. Vaughan, and D. Winker (2005), CALIOP Algorithm Theoretical Basis Document, Part 3: Scene Classification Algorithms, $P C$ SCI-202.

Loosmore, G. (2003), Evaluation and development of models for resuspension of aerosols at short times after deposition, Atmos. Environ., 37, 639-647.

Marticorena, B., and G. Bergametti (1995), Modeling the atmospheric dust cycle: 1 Design of a soil derived dust production scheme, J. Geophys. Res., 100, 16,41516,430 .

Menut, L., C. Schmechtig, and B. Marticorena (2005), Sensitivity of the sandblasting fluxes calculations to the soil size distribution accuracy, Journal of Atmospheric and Oceanic Technology, 22, 1875-1884.

Menut, L., G. Foret, and G. Bergametti (2007), Sensitivity of mineral dust concentrations to the model size distribution accuracy, Journal of Geophysical Research, Atmospheres, 112, D10,210, doi: 10.1029/2006JD007766.

Millan, M., et al. (2005), Climatic feedbacks and desertification: The mediterranean model, Journal of Climate, 18, 684-701.

Mlawer, E. J., S. Taubman, P. Brown, M. Iacono, and S. Clough (1997), Radiative transfer for inhomogeneous atmosphere: RRTM, a validated correlated k-model for the longwave, J. Geophys. Res., 102, 16,663-16,682.

Moreno, T., X. Querol, A. Alastuey, M. Viana, and W. Gibbons (2005), Exotic dust incursions into central spain: Implications for legislative controls on atmospheric particulates, Atmos. Environ., 39, 6109-6120.

Nickovic, S., G. Kallos, A. Papadopoulos, and O. Kakaliagou (2001), A model for prediction of desert dust cycle in the atmosphere, Journal of Geophysical Research, 106, 113-129.

Park, S. H., et al. (2007), Simulation of entrainment and transport of dust particles within north america in april 2001 - red dust episode, J. Geophys. Res., 112, doi: 10.1029/2007JD008443.

Perez, C., S. Nickovic, J. Baldasano, M. Sicard, F. Rocadenbosch, and V. E. Cachorro (2006), A long saharan dust event over the western mediterranean: lidar, sun photometer observations and regional dust modeling, J. Geophys. Res., 111, D15,214, doi: 10.1029/2005JD006579.

Petzold, A., et al. (2006), Saharan Mineral Dust Experiment SAMUM 2006: Airborne observations of dust particle properties and vertical dust profiles, AGU Fall Meeting Abstracts, pp. D214+.

Putaud, J.-P., et al. (2004), A European aerosol phenomenology-2: chemical characteristics of particulate matter at kerbside, urban, rural and background sites in Europe, Atmos. Environ., 38, 2579-2595.

Querol, X., et al. (2004a), Speciation and origin of PM10 and PM2.5 in Spain, Journal of Aerosol Science, 35, 1151-1172.

Querol, X., et al. (2004b), Speciation and origin of PM10 and PM2.5 in selected European cities, Atmos. Environ., 38, 6547-6555.

Querol, X., et al. (2007), Source origin of trace elements in PM from regional background, urban and industrial sites of spain, Atmos. Environ., 41, 7219-7231.

Reisner, J., R. Rasmussen, and R. Bruintjes (1998), Explicit forecasting of supercooled liquid water in winter storms using the MM5 mesoscale model, Q.J.R. Meteor. Soc., 124, 1071-1107.

Schaap, M., et al. (2007), Evaluation of long-term aerosol simulations from seven air quality models and their ensemble in the eurodelta study, Atmos. Environ., p. submitted.

Schmidt, H., C. Derognat, R. Vautard, and M. Beekmann (2001), A comparison of simulated and observed ozone mixing ratios for the summer of 1998 in western Europe, Atmos. Environ., 35, 6277-6297.

Simpson, D., et al. (1999), Inventorying emissions from nature in Europe, Journal of Geophysical Research, 104, 8113-8152.

Sokolik, I., D. M. Winker, G. Bergametti, D. A. Gillette, G. Carmichael, Y. Kaufman, L. Gomes, L. Schuetz, and J. E. Penner (2001), Outstanding problems in quantifying the radiative impact of mineral dust, $J$. Geophys. Res., 106, 18,015-18,028.

Sun, J., M. Zhang, and T. Liu (2001), Spatial and temporal characteristics of dust storms in china and its surrounding regions, 1960-1999, J. Geophys. Res., 106(D10), 10,325-10,334.

Van Dingenen, R., et al. (2004), A European aerosol phenomenology-1: physical characteristics of particulate matter at kerbside, urban, rural and background sites in Europe, Atmos. Environ., 38, 2561-2577.

Van Loon, M., et al. (2007), Evaluation of long-term ozone simulations from seven regional air quality 
models and their ensemble average, Atmos. Environ., 41, 2083-2097.

Vautard, R., B. Bessagnet, M. Chin, and L. Menut (2005), On the contribution of natural aeolian sources to particulate matter concentrations in Europe: Testing hypotheses with a modelling approach, Atmos. Environ., 39, 3291-3303.

Vautard, R., et al. (2003), Paris emission inventory diagnostics from ESQUIF airborne measurements and a chemistry transport model, Journal of Geophysical Research, 108(D17), 8564, doi:10.1029/2002JD002797.

Vautard, R., et al. (2007), Evaluation and intercomparison of ozone and PM10 simulations by several chemistrytransport models over 4 european cities within the citydelta project, Atmos. Environ., 41, 173-188.

Vestreng, V. (2003), Review and Revision. Emission data reported to CLRTAP, Tech. rep., EMEP MSC-W, http://www.emep.int/mscw/mscw_publications.html.

Viana, M., W. Maenhaut, H. M. ten Brink, X. Chi, E. Weijers, X. Querol, A. Alastuey, P. Mikuska, and Z. Vecera (2007), Comparative analysis of organic and elemental carbon concentrations in carbonaceous aerosols in three European cities, Atmos. Environ., 41, 59725983.

Watson, J., and J. Chow (2000), Reconciling urban fugitive dust emissions inventory and ambient source contribution estimates: Summary of current knowledge and needeed research, Desert Research Institute, DRI Document no 6110.4F.

Webb, R. W., C. E. Rosenzweig, and E. R. Levine (2000), Global Soil Texture and Derived Water-Holding Capacities, Available on-line [http://www.daac.ornl.gov] from Oak Ridge National Laboratory.

Winker, D., W. Hunt, and M. McGill (2008), Initial performance assessment of CALIOP, Geophys. Res. Let., p. in press.

Zhang, X. Y., et al. (2003), Characterization of soil dust aerosol in China and its transport and distribution during 2001 ace-asia: 1. network observations, J. Geophys. Res., 108(D9), doi:10.1029/2002JD002632.

Zobler, L. (1986), A world soil file for global climate modeling, NASA Tech. Memo. 87802, p. 33.

Bertrand BESSAGNET, INERIS, Institut National de l'Environnement Industriel et des Risques, Parc technologique ALATA, 60550 Verneuil en Halatte, France. [bertrand.bessagnet@ineris.fr]
This preprint was prepared with AGU's LATEX macros v5.01, with the extension package ' $\mathrm{AGU}^{++}$' by P. W. Daly, version 1.6 from 1999/02/24. 